\title{
Methylcholanthrene-induced Sarcoma in Singly Fractured Bone of Mice
}

\author{
Tsutomu Watanuki and Masayuki Ogata
}

\author{
The Second Department of Pathology (Emeritus Prof. K. Akazaki and \\ Prof. N. Sasano), Tohoku University School of Medicine, Sendai
}

\section{Minoru Yamada}

Department of Orthopedic Surgery (Prof. S. Iino), Tohoku University School of Medicine, Sendai

\begin{abstract}
In order to find a positive correlation between the development of sarcoma of the bone and preceding local traumatic injury, the right femur of dd-strain mice was fractured at the diaphysis, and $0.2 \mathrm{mg}$ of 20 -methylcholanthrene (MO) was injected into the bone marrow or callus at the site of fracture. Various types of sarcoma of the bone developed after various latent periods (57-202 days). A positive sarcoma induction seemed to be related to the histological pattern of the callus at the time of $\mathrm{MC}$-administration.

In the callus composed of already mature cells, no sarcoma developed, while the tumor was induced in $45.5 \%$ of animals with the callus of immature cells after a short latent period. It was assumed that this difference would be due to the different nature of cells composing callus: An active proliferating ability with evident susceptibility to certain carcinogens would be inherent to immature cells but not to mature cells. This would be one of the important factors, which must be taken into consideration in the interpretation of so-called traumatic sarcoma.
\end{abstract}

Much attention has been paid to the induction of sarcoma at the site of single preceding trauma. This type of sarcoma is well-known in the bone and is referred to as 'traumatic sarcoma'. There have been, however, many controversies on this concept, which do not reach an agreement. In the present paper a successful induction of malignant bone tumors of mice in the region of bone fracture is described.

\section{Materials and Methods}

A single fracture was manually made at the diaphysis of the right femur of ddstrain mice. A single dose of $0.2 \mathrm{mg}$ of 20 -methylcholanthrene (MC) was injected into the bone marrow or into the callus of fractured bones.

The animals, 67 in total, were divided into 6 groups according to the length of the interval between fracture and administration of MC (Table 1). The animals of Group 1 were submitted to fracture of the femur immediately after MC-administra-

Received for publication, June 1, 1967. 
TABLE 1. Grouping of experimental animals

\begin{tabular}{|c|c|c|c|}
\hline $\begin{array}{l}\text { No. of } \\
\text { group }\end{array}$ & $\begin{array}{l}\text { Period from fracture } \\
\text { to } \mathrm{MC} \text {-administration }\end{array}$ & $\begin{array}{l}\text { Number of experi- } \\
\text { mental animals }\end{array}$ & $\begin{array}{l}\text { Histological findings of } \\
\text { callus at the time of } \mathrm{MC} \text { - } \\
\text { administration }\end{array}$ \\
\hline & $\begin{array}{l}\text { Fracture was made } \\
\text { immediately after } \\
\text { MC-administration } \\
\text { into the bone marrow } \\
\text { of the right femur }\end{array}$ & 20 & \\
\hline 2 & 5 days & 11 & \\
\hline 3 & 6 days & 8 & $\begin{array}{l}\text { Usually composed of } \\
\text { connective tissue }\end{array}$ \\
\hline 4 & 10 days & 14 & $\begin{array}{l}\text { Concurrent appearance } \\
\text { of connective and }\end{array}$ \\
\hline 5 & 11 days & 5 & $\begin{array}{l}\text { The bone tissue is still } \\
\text { recognizable. }\end{array}$ \\
\hline 6 & 27 days & 9 & $\begin{array}{l}\text { Fracture is almost } \\
\text { cured. Osteoblasts are } \\
\text { sparsely seen arranged } \\
\text { on the surface of the } \\
\text { newly formed immature } \\
\text { trabecle and cortex. }\end{array}$ \\
\hline
\end{tabular}

tion into the bone marrow in situ. In the other 5 groups, MC was given 5 to 27 days after fracture.

Rate of sarcoma development: The animals which were injected MC 11 days after fracture (Group 5) died without developing tumor. Furthermore, no tumor was observed in the animals, of which bones had been fractured immediately after MC-administration (Group 1) and in the animals, which had received MC-injection 27 days after the fracture (Group 6). On the contrary, in the animals with MCadministration 5,6 and 10 days (in Groups 2,3 and 4, respectively) after the fracture, malignant tumor was confirmed in 6,2 and 7 cases, respectively. In these three groups, the incidence of the tumor in relation to the effective total number was very high and attained or exceeded $50 \%$.

Latent period: The period between administration of $\mathrm{MC}$ and development of grossly detectable tumor ranged from 57 to 202 days. The shortest period was observed in three cases in Group 2 and one case in Group 3. The tumors measured $10 \times 9 \times 9 \mathrm{~mm}$ to $16 \times 14 \times 14 \mathrm{~mm}$ or more in size. Roentgenologically, the findings suggestive of destruction and resorption of the osseous cortex were confirmed in the fractured lesion almost in every case. Grossly, a majority of the tumor was soft in consistency and the cut surface was usually glistening, semitransparent and grayish white in color. Whirlpool structures were occasionally observed. Histologically, fibrosarcoma was most prevalent and followed by pleomorphic cell sarcoma. Osteo- 
TABLE 2. Relationship among fracture, MC-administration and occurrence of the tumor

\begin{tabular}{|c|c|c|c|c|c|c|c|}
\hline $\begin{array}{l}\text { No. of } \\
\text { group }\end{array}$ & $\begin{array}{l}\text { Period } \\
\text { from } \\
\text { fracture } \\
\text { to MC- } \\
\text { adminis- } \\
\text { tration }\end{array}$ & $\begin{array}{c}\text { Number } \\
\text { of experi- } \\
\text { mental } \\
\text { animals }\end{array}$ & $\begin{array}{c}\text { Effective } \\
\text { total } \\
\text { number }\end{array}$ & $\begin{array}{c}\text { Incidence } \\
\text { of } \\
\text { sarcoma }\end{array}$ & $\begin{array}{l}\text { Rate of } \\
\text { occur- } \\
\text { rence of } \\
\text { sarcoma }\end{array}$ & $\begin{array}{l}\text { Period from } \\
\text { MC-adminis- } \\
\text { tration to } \\
\text { occurrence of } \\
\text { sarcoma }\end{array}$ & $\begin{array}{l}\text { Histological } \\
\text { diagnosis of } \\
\text { tumor }\end{array}$ \\
\hline 1 & $\begin{array}{l}\text { At the } \\
\text { frac- } \\
\text { ture }\end{array}$ & 20 & 20 & 0 & 0 & & \\
\hline 2 & 5 days & 11 & 11 & 6 & $54.5 \%$ & $\begin{array}{l}57 \text { days } \\
57 \text { days } \\
57 \text { days } \\
99 \text { days } \\
119 \text { days } \\
160 \text { days }\end{array}$ & $\begin{array}{l}\text { Pleomorphic } \\
\text { cell sarcoma } \\
\text { Pleomorphic } \\
\text { cell sarcoma } \\
\text { Pleomorphic } \\
\text { cell sarcoma } \\
\text { Pleomorphic } \\
\text { cell sarcoma } \\
\text { Fibrosarcoma } \\
\text { Spindle cell } \\
\text { sarcoma }\end{array}$ \\
\hline 3 & 6 days & 8 & 3 & 2 & $66.6 \%$ & $\begin{array}{l}57 \text { days } \\
99 \text { days }\end{array}$ & $\begin{array}{l}\text { Fibrosarcoma } \\
\text { Fibrosarcoma }\end{array}$ \\
\hline 4 & 10 days & 14 & 14 & 7 & $50.0 \%$ & $\begin{array}{l}99 \text { days } \\
149 \text { days } \\
149 \text { days } \\
160 \text { days } \\
170 \text { days } \\
170 \text { days } \\
202 \text { days }\end{array}$ & $\begin{array}{l}\text { Fibrosarcoma } \\
\text { Fibrosarcoma } \\
\text { Fibrosarcoma } \\
\text { Fibrosarcoma } \\
\text { Fibrosarcoma } \\
\text { Osteochondro- } \\
\text { plastic sarcoma } \\
\text { Fibrosarcoma }\end{array}$ \\
\hline 5 & 11 days & 5 & 0 & & & & \\
\hline 6 & 27 days & 9 & 9 & 0 & 0 & & \\
\hline
\end{tabular}

chondroplastic sarcoma was observed in one case.

\section{Discussion and Conclusion}

Two opposing opinions have been known concerning the relationship between preceding trauma and occurrence of tumor. One opinion denies the possibility of trauma as a major factor of tumor induction based upon both clinical and experimental observations. ${ }^{1-5}$ The other stresses that trauma directly activates either the latent proliferative ability of the embryonal stray germ ${ }^{6}$ or of separated tissue cells, ${ }^{7}$ or evokes tumor producing predisposition inherent to cells. ${ }^{8,9}$ In the latter mechanism secondary tissue changes such as circulatory disturbance, inflammation or tissue proliferation were regarded to play an important part in the tumor induction. ${ }^{10-15}$ Actually, not a few examples of sarcoma with a close relationship to preceding trauma have been reported. Furthermore, there are several 
experimental studies indicating the probable influence of preceding trauma on the tumor induction. ${ }^{16-18}$

In our experiment, no occurrence of tumor was seen in the animals with MCinjection immediately before or 27 days after the fracture (Groups 1 and 6), whereas the animals with MC-administration 5, 6 or 10 days after the fracture (Groups 2,3 and 4) had high tumor induction rates of $50 \%$ or more. In these three groups, the latent period was considerably short, the shortest period being only 57 days after MC-administration.

It is assumed that such differences of tumor incidence between Groups 1 and 6 on the one hand and Groups 2, 3 and 4 on the other are due to difference in the stage of histological repair of fracture at the time of MC-administration. In the groups without tumor development, MC was either administered into the bone marrow before immature cells proliferated (Group 1), or given at the time when newly proliferating cells in the callus had fairly completed their maturation (Group 6). On the contrary, numerous immature cells were present in actively proliferating tissues of the callus at the time of MC-administration in Groups 2, 3 and 4. Therefore, it is reasonable to assume that tumor induction of the callus by $\mathrm{MC}$ was associated with the presence of immature cells in the callus. The generally accepted concept that 'immature cells are very susceptible to some carcinogenic action than mature cells' appears to be applicable to the interpretation of our experimental results.

In conclusion, the predominance of tumor after trauma is attributed to appearance of actively proliferating immature mesenchymal cells in the course of wound healing. Traumatic injuries probably acts as one of the factors accelerating tumor development, rather than as a causative factor.

\section{References}

1) Ewing, J. Neoplastic Diseases. A Treatise on Tumors, 2nd ed., W.B. Saunders Co., Philadelphia \& London, 1922, pp. 109-112.

2) Knox, L.C. Trauma and tumors. Arch. Path., 1929, 7, 274-309.

3) Martland, H.S. The occurrence of malignancy in radioactive persons. Amer. $J$. Cancer, 1931, 15, 2435-2516.

4) Stewart, F.W. Cancer said to be caused by a single trauma. J. Amer. med. Ass., $1944,126,125$.

5) Coley, B.L. Trauma in malignant tumors of bone. Amer. J. Surg., 1947, 73, 300-304.

6) Cohnheim, J. Vorlesungen iiber allgemeine Pathologie. August Hirschwa]d, Berlin, 1882, pp. 732--753.

7) Ribbert, Ủber die Entstehung der Geschwülste. Disch. med. Wschr., 1895, 21, 9-11, $24-26,45-47,62-64$.

8) Widmann, E. Die Bedeutung des Traumas für die Entstehung von Sarkomen. Bruns' Beitr. klin. Chir., 1918, 111, 721-736.

9) Philippsberg, $\mathrm{K}$. Ủber traumatisch entstandenes Sarkom. Klin. Wschr., 1922, 1, $2385-2386$.

10) Jordan. Über die Entstehung von Tumoren, Tuberkulose und anderen Organerkrankungen nach Einwirkung stumpfer Gewalt. Münch. med. Wschr., 1901, 48, 17411746. 
11) Theilhauber, A. Der Zusammenhang von stumpfen Traumen mit der Entstehung von Carcinomen und Sarkomen. Dtsch. Z. Chir., 1911, 110, 77-88.

12) Hartmann, K. Beiträge zur Frage des Sarkoms nach Trauma. Bruns' Beitr. klin. Chir., 1914, 88, 572-579.

13) Pick, L. Zur traumatische Genese der Sarkome. Med. Klin., 1921, 17, 406-409.

14) Fränkel, E. U̇ber Trauma und Sarkomentstehung. Miinch. med. Wschr., 1921, 16, 1278-1280.

15) Pels-Leusden. Kriegsverletzung und Sarkom. Zbl. Chir., 1930, 57, 2857-2858.

16) Lipschütz, B. Untersuchungen über die Entstehung des experimentellen Teercarinoms der Maus. Z. Krebsforsch., 1924, 21, 50-97.

17) Dellman, H.T. Die Entstehung des experimentellen Teerkrebses und die Bedeutung der Zellenregeneration. Z. Krebsforsch., 1924, 21, 220-226.

18) Hellner, H. Experimentelle Knochensarkome und ihre Beziehungen zu allgemeinen Geschwulstproblemen. Bruns' Beitr. klin. Chir., 1938, 168, 538-553. 